\title{
Sport Entrepreneurs' Perspective on 4.0 Industrial Era
}

\author{
Mochamad Arifin \\ Department of Sport Coaching Education \\ Surabaya State University \\ Surabaya, Indonesia \\ arifinbaritoputera@gmail.com
}

\author{
Muchamad Arif Al Ardha \\ Physical Education Department \\ Universitas Negeri Surabaya \\ Surabaya, Indonesia \\ muchamadalardha@unesa.ac.id
}

\section{RESEARCH METHOD}

\begin{abstract}
Internet is a key factor of 4.0 industrial era. It provides opportunities for sport industry to develop well. However, the important issue is how to manage the sports industry to be adaptable with the 4.0 industrial era. This study aims to inquire the perspective of sports entrepreneurs on managing their industry in 4.0 industrial era. This study employs a mix methods study which was conducted by survey and interview methods. There were sixteen sport entrepreneurs from five provinces in Indonesia. Each of them has filled the questionnaires about the sport industry in 4.0 industrial era and was interviewed by semi-structured interview method. The results show that the $\mathbf{4 . 0}$ industrial era influences the sports industry, particularly on the management and marketing. However, the innovation is not influenced dramatically due to specific and unique product of each sporting industry. In conclusion, there must be a new strategy to be applied in the management and marketing of sports industry in the 4.0 industrial era.
\end{abstract}

Keywords: sport entrepreneurs, sport industry, industry 4.0

\section{INTRODUCTION}

Industry 4.0 was introduced at the Hannover Messe industry exhibition in the city of Hannover, Germany in 2011. It emphasizes on internet, computer, robot, and artificial intelligence as industry bases. It is recognized as a smart industry [1]. Industry 4.0 provides opportunities for every industry including the sports industry, to enhance their business [2]. The role of the internet can support innovation, management, and marketing [3]. However, there are limited studies that observe the utilization of the official website and social media in sports industry.

Sport industry has its own unique characteristics. It has many customer segmentations and offers many kinds of products [4]. These unique characteristics may benefit the sports industry if it can be developed and managed well[5]. Furthermore, the successful development of sports industries will contribute to the national economic growth[6]. However, less is known about sports industry management in 4.0 industrial era from an entrepreneurs' perspective. This study aims to inquire the perspective of sports entrepreneurs on managing their industry in the 4.0 industrial era.

\section{A. Research Design}

This study utilized a mixed-method approach. It used a survey to identify the general information, and semi-structured interviews were also conducted to inquire deeper information from the research subjects.

\section{B. Research Sample}

There were sixteen research subjects from 5 provinces in Indonesia, which were selected by purposive sampling (Fig. 1). Based on the industrial purposes, $81 \%$ of research subjects are in the professional sector and $19 \%$ of research subjects are in the amateur sector (Fig. 2). Based on their product, there are $44 \%$ of research subjects selling goods, $19 \%$ rent sports facilities or places, $19 \%$ supply services, $19 \%$ offer ideas, and $6 \%$ offer agencies (Fig. 3). Based on the market, there are 13 $\%$ of research subjects providing their products for the local market, $31 \%$ regional market, and $56 \%$ national market (Fig. 4).

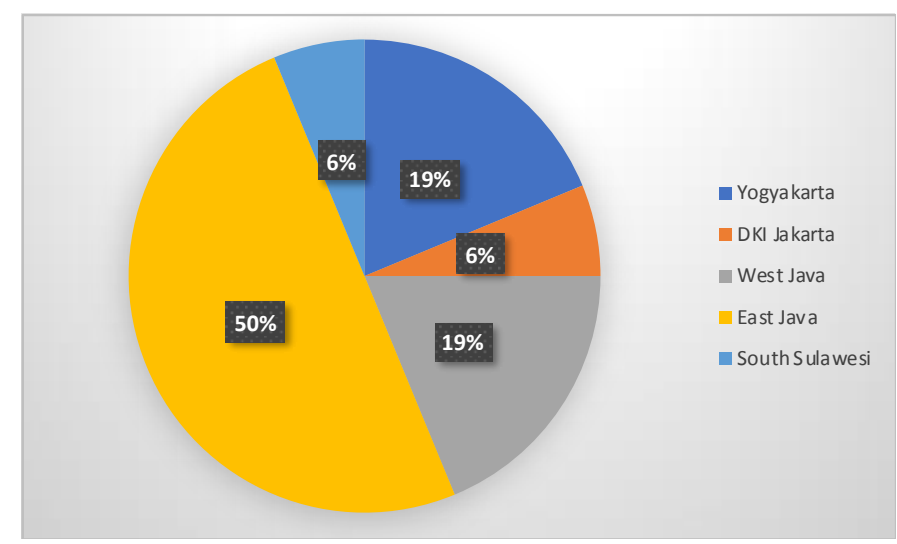

Fig. 1. Research subjects based on the origin 
TABLE I. INTERNET UTILIZATION

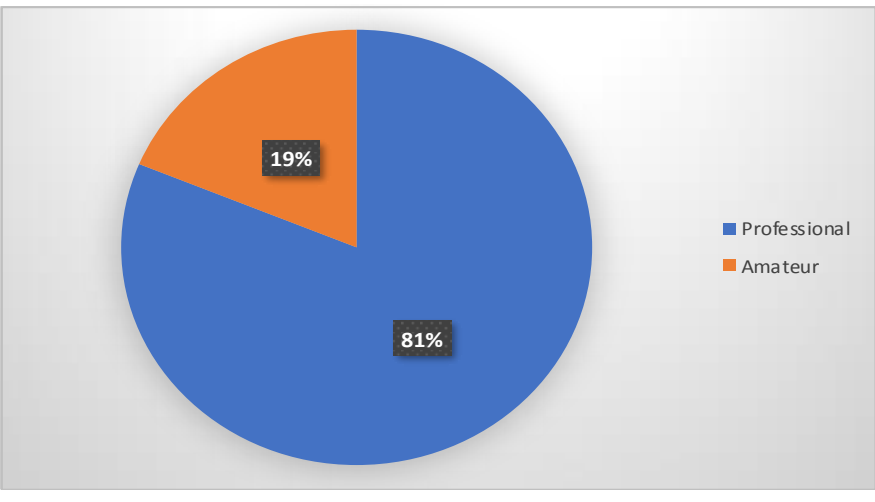

Fig. 2. Research subjects based on the origin

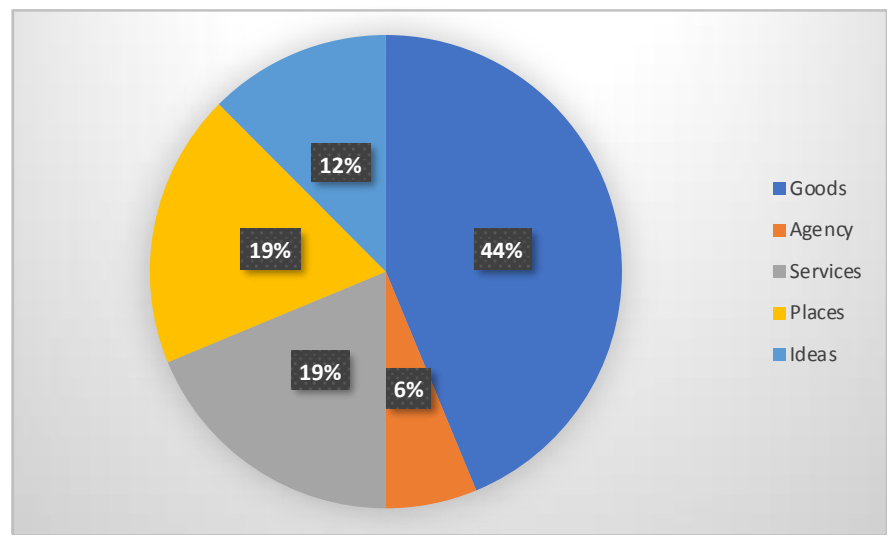

Fig. 3. Research subjects products

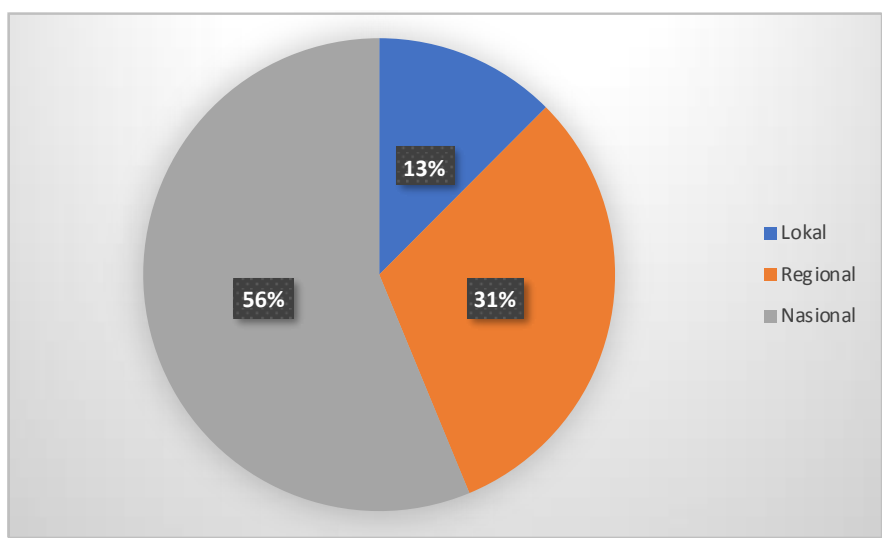

Fig. 4. Research subjects markets

\section{RESULTS AND DISCUSSION}

Overall, almost all research subjects have been using social media as their tools in marketing. However, there are only a few of them who utilize the internet to develop their business by establishing collaboration with other institutions and foreign companies.

\begin{tabular}{|l|c|c|c|}
\hline \multirow{2}{*}{} & \multicolumn{3}{|c|}{ Average } \\
\cline { 2 - 4 } & Innovation & Management & Marketing \\
\hline $\begin{array}{l}\text { Official } \\
\text { Website }\end{array}$ & $43.75 \%$ & $37.50 \%$ & $62.50 \%$ \\
\hline $\begin{array}{l}\text { Social } \\
\text { media }\end{array}$ & $81.25 \%$ & $62.50 \%$ & $93.75 \%$ \\
\hline
\end{tabular}

\section{A. Innovation}

Business innovation means adapting the current invention and trend which are suitable with the industry [7]. It is necessary to make a continuous innovation in sports industry [3]. There are thirteen research subjects who use social media to update the information and get new ideas and seven research subjects who use official website to gain inspiration and innovation. All research subjects working on designing product and making a thing use social media frequently. On the other hand, the research subjects who work in the services and agency use the official website more.

During the interview, some research subjects explained the importance of YouTube to make innovation. They use it as a learning resource to gain more information other than online books and magazines. In conclusion, all of the research subjects agree that the vital role of online resources is to broaden their creativity. Furthermore, online resources are more likely to be used because it is free but provides adequate information. There is plenty of online information; however, the sports industry manager has a critical role to decide the application of innovation [8]. Mostly, innovation will not be executed dramatically in the sports industry because every company has its own product's characteristic and identity.

\section{B. Management}

Management in the sport industry could be interpreted as an understanding among sports entrepreneur, current investors, and future investors [3]. Furthermore, managing the sport industry requires a complex capability to understand the market deeply. It also requires an intent for communication to update a piece of new information daily. There are ten research subjects who use social media to communicate and manage their industry. Moreover, twelve research subjects utilize the official website as their database and human resource management.

In the sport industry, management skill is also needed to obtain more customer. Managing the customer by social media and the official website has been proven significantly and effectively. It was also stated by the research subject who emphasizes the importance of customer interaction in the social media and official website. Furthermore, this interaction creates social entrepreneurship in the sports industry [9].

\section{Marketing}

Marketing is an understanding of market segmentation and purchasing capability [3]. In the sport industry, market segmentation could be divided into sports performance, sports production, and sports promotion [10]. Most of the research subjects work in sport production. Furthermore, some of the research subjects operate sports promotion and three research subjects deal with sports performance. All these segmentations could be advertised by online marketing. Furthermore, this 
virtual market has also created simple payment methods which can possibly allow the costumer to buy the goods and services that they need.

As a result, all of the research subjects use online media to promote their product. There are fifteen research subjects use social media to boost their marketing value. Furthermore, there are nine research subjects who use both social media and the official website. All of the research participants believe that online marketing has a much larger market than traditional marketing. Consequently, some sports industries hire professional content makers to make their product become more interesting in the online market.

\section{CONCLUSION}

In conclusion, the 4.0 industry era has been creating its own structure. Overall, it gives a positive impact to the sports industry. Online marketing is the best example to illustrate how quickly a brand could establish and increase its popularity [11]. However, there must be a new strategy and skill to be applied in this 4.0 industry era. One of the most important is customer safety [12]. The role of government and other law regulators are very critical to create a safe transaction in online marketing.

\section{REFERENCES}

[1] T. Mazali, "From industry 4.0 to society 4.0, there and back," AI Soc., vol. 33, no. 3, pp. 405-411, Aug. 2018.

[2] S. Saniuk, A. Saniuk, and D. Cagáňová, "Cyber Industry Networks as an environment of the Industry 4.0 implementation," Wirel. Networks, pp. 1-7, Jul. 2019.

[3] T. Hayduk and M. Walker, "Mapping the strategic factor market for sport entrepreneurship," Int. Entrep. Manag. J., vol. 14, no. 3, pp. 705-
724, Sep. 2018

[4] M. A. Hums, C. A. Barr, and L. Gullion, "The Ethical Issues Confronting Managers in the Sport Industry," J. Bus. Ethics, vol. 20, no. 1, pp. 51-66, 1999.

[5] V. Ratten, "Sport-based entrepreneurship: towards a new theory of entrepreneurship and sport management," Int. Entrep. Manag. J., vol. 7, no. 1, pp. 57-69, Mar. 2011.

[6] C.-T. Hsiao, H.-L. Peng, and H.-H. Huang, "The impact of sports ethics of professional baseball player to the development of sports industry in Taiwan," Qual. Quant., vol. 46, no. 6, pp. 1753-1767, Oct. 2012.

[7] J. Qian and R. Law, "Vincenzo Morabito: The future of digital business innovation: trends and practices," Inf. Technol. Tour., vol. 16, no. 4, pp. 459-461, Dec. 2016.

[8] F. Wemmer and J. Koenigstorfer, "Open Innovation in Nonprofit Sports Clubs," Volunt. Int. J. Volunt. Nonprofit Organ., vol. 27, no. 4, pp. 1923-1949, Aug. 2016.

[9] V. Ratten, "Social Entrepreneurship in Sport," in Sports Technology and Innovation, Cham: Springer International Publishing, 2019, pp. 73-93.

[10] B. Pitts, L. Fielding, and L. Miller, "Industry segmentation theory and the sport industry: Developing a sport industry segment model," Kinesiol. Fac. Publ., Jan. 1994.

[11] N. Aggrawal, A. Ahluwalia, P. Khurana, and A. Arora, "Brand analysis framework for online marketing: ranking web pages and analyzing popularity of brands on social media," Soc. Netw. Anal. Min., vol. 7, no. 1, p. 21, Dec. 2017.

[12] L. Brooks and A. Airey, "Consumer Privacy and Online Marketing: Bringing the Human Back into the Picture," Springer, Boston, MA, 2001, pp. 203-210. 